\title{
Relationship Between Knowledge And Perceptions Of Geodiversity, Biodiversity, And Cultural Diversity With The Formation Of Students' Environmental Care Attitudes To The Existence Of The Ciletuh Pelabuhanratu Geopark Area
}

\author{
Nurul Sucyati ${ }^{1}$, Ahmad Yani ${ }^{2}$, Nandi $^{3}$ \\ $\left\{\underline{\text { nurulsucyati@upi.edu }}^{1}, \underline{\text { ahmadyani@upi.edu }}^{2}\right.$, nandi@upi.edu $\left.{ }^{3}\right\}$
}

Postgraduate School, Geography Education Program, Indonesia University of Education ${ }^{1,2,3}$

\begin{abstract}
This research aims to determine the relationship between knowledge and perceptions of geodiversity, biodiversity, and cultural diversity on environmental care attitudes. There is a legal protection that underlies all parties to know and participate in maintaining the preservation of geopark, including students. So that it requires information about knowledge and perceptions about aspects of geoparks (geodiversity, biodiversity, cultural diversity) of students towards the formation of environment care attitudes to participate in the education pillar to protect and preserve geopark. The method in this research is a survey with a quantitative approach. The sample data in this study were collected from 356 respondents with a random sampling technique. Data analysis using SPSS application to find descriptive statistics, bivariate test, and multivariate test. The results show that there is a relationship between knowledge and perception of environmental care attitudes and has an influence of $37,2 \%$
\end{abstract}

Keywords: Geopark, knowledge, perceptions, and environmental care attitudes

\section{Introduction}

Ciletuh-Pelabuhanratu Geopark has extraordinary features because of geological characteristics that are not found elsewhere; it makes Ciletuh a geopark [1]. One of the uniqueness of the Ciletuh Geopark is that it has a geological heritage site of international value in plate collisions between continental plates and oceanic plates during the Karst era. As a result of this event, a complete natural theater was created. The requirements of a geopark must contain three aspects: Geodiversity, Biodiversity, and Cultural Diversity. The primary legal protection in Geopark aims to prevent or prevent natural damage and nature conservation with the main legal task of maintaining legal certainty so that later order and balance in environmental protection and management are guaranteed [2].

There is a legal that underlies all parties, both the government and the community, to know and maintain the Ciletuh-Pelabuhanratu geopark's sustainability. As contained in the Law 
of the Republic of Indonesia No. 32 (2009) Chapter 1 General provisions of article (1), the second point concerning Environmental Protection and Management that environmental protection and management is a systematic and integrated effort carried out to preserve environmental functions and prevent the occurrence of environmental pollution/damage which includes planning, utilization, control, maintenance, supervision and law enforcement [3]. The key to the success of Geopark development and management lies in the role and participation of local communities who are active and understand the meaning of Geopark itself. Unfortunately in the Ciletuh-Pelabuhanratu Geopark area, some people still do not understand the importance of Geopark and still carry out stone mining and forest logging, which are contradictory with sustainable development [4].

Geopark has three pillars: conservation, education, and economic development, so students are required to play a role in the education pillar to protect and preserve the earth park. One of the main steps in inviting students to join in protecting and maintaining Geopark. It requires information about the knowledge and perceptions of students about the CiletuhPelabuhanratu geopark area. The level of teacher knowledge of geoparks as a learning resource is still low. This impacts the common utilization of Geoparks by teachers as a learning resource [5]. Our nation hopes to have the next generation who can save the environment because Indonesia as a country is rich in natural resources [6]. As the nation's generation which is an asset for development actors in the future, it is necessary to instill the proper knowledge so that it can be used as a provider of knowledge, the formation of positive behavior and attitudes that are embedded in them until later stepping into adulthood [7].

It is essential to investigate the relationship between knowledge and perception on the formation of students' environmental care attitudes because perception and cognition (ability) is needed in all psychological activities [8]. Psychological activities mean building a philosophy of caring for the environment among students to maintain the preservation of the CiletuhPelabuhanratu geopark. The caring attitude and culture of the domain from the school community are expected to be transmitted/impact the community around the school to create a community that has the character of caring for the environment [9]. This information data can be used as a reference and government policy to see how the level of knowledge and perceptions of students on the Cilteuh-Pelabuhanratu area.

\section{Literature Review}

\section{Management and Value of Geopark Areas for the Community}

Geopark is a single or combined geographic area, which has valuable sites and landscapes related to heritage, geodiversity, biodiversity, and cultural diversity aspects; it is managed for conservation, education, and sustainable community economic development with the active involvement of the community and local government, so that it can be used to built public understanding and concern for the earth and the surrounding environment.[10].

The geological community in Europe initiated parks in the 2000s. They wanted to protect some critical geological sites in Europe because geological aspects were not too sensitive to changes, so the Geopark was born. All geological phenomena interesting, beautiful, rare, have a tourist attraction can be a geopark. Important geological sites must be introduced to realize the importance of these geological sites and take advantage of their environmental benefits [11]. As a geopark, it must have three main components: geodiversity, biodiversity, and cultural 
diversity. These components are interrelated and become the focus for conservation, education, and community economic development.

Geodiversity is a description of the uniqueness of geological components such as minerals, rocks, fossils, geological structures, and landscapes that are the essential wealth of an area and the existence, distribution, and conditions that can represent the geological evolution process of the site [12]. Geological objects consist of mineral elements, rocks, fossils, geological/tectonic/process structures, landscapes. Biodiversity is the wealth of life on earth, millions of plants, animals, and microorganisms, the genetics they contain, and the ecosystems they build into the living environment [13]. Cultural diversity in the past and the present culture, both tangible and intangible [14].

\section{Relationship between Knowledge and Individual Perception on the Formation of Environmental Care Attitude}

Knowledge is a sensory process, especially the eyes and ears on particular objects. Knowledge is a critical domain in the formation of overt behavior [15]. In the world of education, there are six categories of cognitive processes that are often found, according to Anderson \& Krathwohl: Remembering (C1), Understanding (C2), Applying (C3), Analysis (C4), Evaluation (C5), and Creating (C6) [16]. Perception is a process to translate all information obtained from the environment through sight, hearing, appreciation, and feeling [8]. Research on perception has consistently shown that different people may see the same thing but perceive it differently. The reality is that none of us see reality. What they do is interpret what we see and call it reality [17]. Attitude begins with feelings (likes or dislikes) associated with a person's tendency to respond to something/object. Attitude is also an expression of the values or view of life owned by a person [18]. Various factors that influence attitudes include personal experience, culture, significant other, mass media, educational institutions or religious institutions, and emotional factors within the individual Methodology [19].

\section{Research Methods}

This research is a quantitative approach survey research method. This study aims to reveal the knowledge and perceptions of students about geodiversity, biodiversity, and cultural diversity in the Ciletuh-Pelabuhanratu geopark area. In addition, it also looks for the relationship between knowledge and perception of the formation of attitudes of high school students.

\section{Population and sampling}

The population comprises elementary units with the same essential characteristics or are considered the same [20], which important factors are reflected in the form of specific measurements. The population of this study was all students in the Ciletuh geopark area, there are seven schools: SMAN 1 Cisolok, SMAN 1 Cikakak, SMAN 1 Pelabuhanratu, SMAN 1 Simpenan, SMAN 1 Ciracap, SMAN 1 Ciemas, and SMAN 1 Surade. The total population is 5,548 . While for the research sample, as many as 356 respondents were taken by random sampling technique. This random sampling technique is recommended by Creswell in which every individual in the population has the same probability of being selected [21]. 


\section{Instrument And Measurement}

Measuring students' knowledge about geodiversity, biodiversity, and cultural diversity is done through a test in the form of multiple-choice questions as many as 30 questions. The measurement of students' environmental perceptions and attitudes about geodiversity, biodiversity, and cultural diversity is carried out through a questionnaire using the Likert scale guideline in the scoring.

\section{Data Analysis}

All data collected were analyzed through descriptive and statistical tests, including bivariate test using the chi-square formula to find the relationship between variables $\mathrm{X} 1$ to $\mathrm{Y}$ and $\mathrm{X} 2$ to $\mathrm{Y}$. and multivariate test using linear regression. This analysis relates to all statistical techniques that simultaneously analyze several measurements on individuals or objects [22].

\section{Result And Discussion}

\section{Descriptive statistics}

Based on the results of the study, it showed that the level of knowledge of high school students in the Ciletuh Geopark area consisted of five levels including Very Poor as many as 57 respondents, Poor as many as 105 respondents, Fair as many as 56 respondents, Good as many as 109 respondents, and Very Good as many as 29 respondents. More details can be seen in the following diagram.

\section{Knowledge Level}

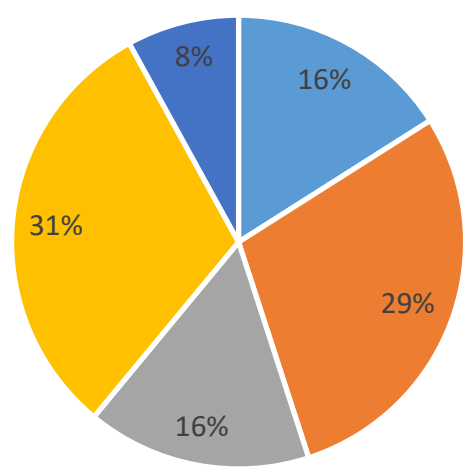

- Very Poor $\quad$ - Poor $\quad$ Fair $\quad$ - Good $\quad$ Very Good

Fig.1 Knowledge level of Geodiversity, Biodiversity, and Cultural Diversity Source: analysis result, 2021 
Table 1. Distribution of Respondents Based on Knowledge Level

\begin{tabular}{ccc}
\hline Knowledge level & Frequency & $\begin{array}{c}\text { Percentage } \\
(\mathbf{\%})\end{array}$ \\
\hline Very Poor & 57 & 16 \\
Poor & 105 & 29 \\
Fair & 56 & 16 \\
Good & 109 & 31 \\
Very Good & 29 & 8 \\
$\mathbf{N}$ & $\mathbf{3 5 6}$ & $\mathbf{1 0 0}$ \\
\hline
\end{tabular}

Based on table 1, it can be concluded that the level of knowledge of high school students in the Ciletuh-Pelabuhanratu geopark area based on the order from highest to lowest is in the Good, Poor, Very Poor, Fair, and Very Good categories. Descriptive analysis is also carried out on the level of knowledge of students to find the minimum value, which means the lowest value of the respondent, maximum means the highest value of the respondent, the mean means the average value of the respondent's knowledge. Standard deviation implies the distribution of several data values. Based on the results of descriptive statistics, the mean value is 50.7697 or rounded up to 51 . The mean number of 51 means that students' overall level of knowledge is in the fair category.

Meanwhile, the standard deviation of 24,29427 means that it is getting closer to the average. The higher the number, the wider the data range. The following are the results of the descriptive statistical analysis in table 2 .

Table 2. Knowledge level descriptive statistics

\begin{tabular}{lrrrrr}
\hline & N & Minimum & Maximum & Mean & $\begin{array}{c}\text { Std. } \\
\text { Deviation }\end{array}$ \\
\hline Knowledge & 356 & 7.00 & 100.00 & 50.7697 & 24.29427 \\
Valid N (listwise) & 356 & & & & \\
\hline
\end{tabular}

The research results on the perception category of high school students in the Ciletuh Pelabuhanratu geopark area consisted of four categories, including Poor as many as two respondents, Fair as many as 22 respondents, Good as many as 213 respondents, and Very good as many as 119 respondents. More details can be seen in the following diagram. 


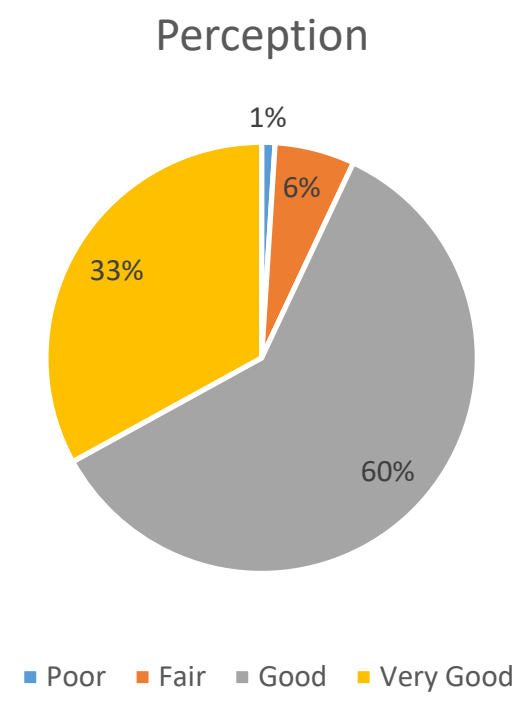

Fig.2 Student Perception of Geodiversity, Biodiversity, and Cultural Diversity

Table 3. Distribution of Respondents Based on Perception

\begin{tabular}{ccc}
\hline Perception & Frequency & $\begin{array}{c}\text { Percentage } \\
(\boldsymbol{\%})\end{array}$ \\
\hline Poor & 2 & 1 \\
Fair & 22 & 6 \\
Good & 213 & 60 \\
Very Good & 119 & 33 \\
N & $\mathbf{3 5 6}$ & $\mathbf{1 0 0}$ \\
\hline
\end{tabular}

Based on table 3, it can be concluded that the perceptions of high school students in the Ciletuh-Pelabuhanratu geopark area based on the order from highest to lowest are in the Good, Very good, Fair, Poor categories. The descriptive statistics show that the maximum value is 100 , the minimum value is 38 , the mean value is 76.6320 or rounded up to 71 , which means that the overall weight is categorized as good. The standard deviation value is 11.44304, which means that the lower is closer to the average. The following are the results of descriptive statistics on perceptions in table 4 .

Table 4. Descriptive Statistics Perception

\begin{tabular}{llllll}
\hline & N & Minimum & Maximum & Mean & Std. Deviation \\
\hline Perception & 356 & 38.00 & 100.00 & 76.6320 & 11.44304 \\
Valid N (listwise) & 356 & & & & \\
\hline
\end{tabular}

Based on the results of the study, it shows that the environmental care attitude of high school students in the Ciletuh Geopark area consists of five levels including Very Poor as many as seven respondents, Poor as many as 27 respondents, Fair as many as 56 respondents, Good 
as many as 117 respondents, and Very Good 149 respondents. More details can be seen in the following diagram.

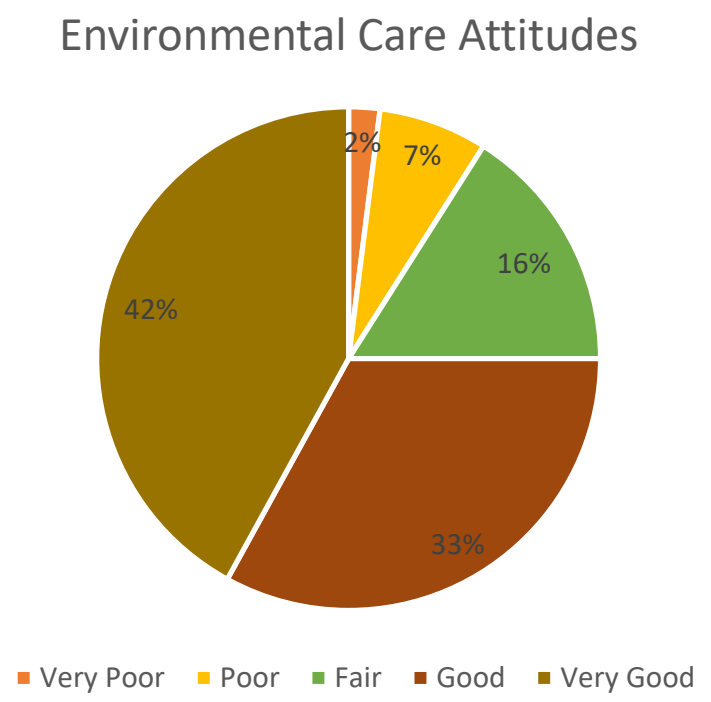

Fig.3 Student Environmental Care Attitude Of Geodiversity, Biodiversity, and Cultural Diversity

Table 5. Distribution of Respondents Based on Environmental Care Attitudes

\begin{tabular}{ccc}
\hline $\begin{array}{c}\text { Environmental care } \\
\text { attitudes }\end{array}$ & Frequency & $\begin{array}{c}\text { Percentage } \\
(\boldsymbol{\%})\end{array}$ \\
\hline Very Poor & 7 & 2 \\
Poor & 27 & 7 \\
Fair & 56 & 16 \\
Good & 117 & 33 \\
Very Good & 149 & 42 \\
$\mathbf{N}$ & $\mathbf{3 5 6}$ & $\mathbf{1 0 0}$ \\
\hline
\end{tabular}

Based on table 5, it can be concluded that the environmental care attitude of high school students in the Ciletuh-Pelabuhanratu geopark area based on the order from highest to lowest is in the Very Good, Good, Fair, Poor, and Very Poor categories. The results of descriptive statistics show that the maximum value is 100 , the minimum value is 10 , the mean value is 74.9579 or rounded up to 75 , which means that the overall weight is categorized as good, and the standard deviation value is 22.02587, which means that the lower, the closer to the average. The following are descriptive statistics in table 6

Tabel 6. Descriptive statistics Environmental care attitude

\begin{tabular}{lrrrrr}
\hline & N & Minimum & Maximum & Mean & Std. Deviation \\
\hline $\begin{array}{l}\text { Environmental care } \\
\text { attitude }\end{array}$ & 356 & 10.00 & 100.00 & 74.9579 & 22.02587 \\
\hline
\end{tabular}




\section{Bivariate Test}

The chi-square test of knowledge and environmental care attitude shows that the value of $p=0.000$. This means that the value of $p=0.000<\operatorname{sig} 0.05$. Based on this value, hypothesis $\mathrm{H} 1$ is accepted, and $\mathrm{Ho}$ is rejected, or the level of knowledge has a significant relationship with the students' environmental care attitude. For more details, see table 7.

Table 7. Cross Tabulation of Knowledge and Environmental Care

\begin{tabular}{|c|c|c|c|c|c|c|c|c|}
\hline & & & & Environ & ental ca & e attitu & & Total \\
\hline & & & Very Poor & Poor & Fair & Good & Very Good & \\
\hline & Very Poor & Frequency & 1 & 2 & 6 & 15 & 41 & 65 \\
\hline & & Percentage & $1.5 \%$ & $3.1 \%$ & $9.2 \%$ & $23.1 \%$ & $63.1 \%$ & $100 \%$ \\
\hline & Poor & Frequency & 0 & 6 & 15 & 41 & 52 & 114 \\
\hline & & Percentage & $0.0 \%$ & $5.3 \%$ & $13.2 \%$ & $36.0 \%$ & $45.6 \%$ & $100,0 \%$ \\
\hline 总 & Fair & Frequency & 2 & 2 & 15 & 23 & 29 & 71 \\
\hline 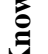 & & Percentage & $2.8 \%$ & $2.8 \%$ & $21.1 \%$ & $32.4 \%$ & $40.8 \%$ & $100.0 \%$ \\
\hline & Good & $\begin{array}{l}\text { Frequency } \\
\text { Percentage }\end{array}$ & $\begin{array}{c}3 \\
3.2 \%\end{array}$ & $\begin{array}{c}14 \\
15.1 \%\end{array}$ & $\begin{array}{c}20 \\
21.5 \%\end{array}$ & $\begin{array}{c}31 \\
33.3 \%\end{array}$ & $\begin{array}{c}25 \\
26.9 \%\end{array}$ & $\begin{array}{c}93 \\
100.0 \%\end{array}$ \\
\hline & Very Good & Frequency & 1 & 2 & 1 & 7 & 2 & 13 \\
\hline & & Percentage & $7.7 \%$ & $15.4 \%$ & $7.7 \%$ & $53.8 \%$ & $15.4 \%$ & $100 . \%$ \\
\hline & & $\mathrm{N}$ & 7 & 26 & 57 & 117 & 149 & 356 \\
\hline & Total & Percentage & $2.0 \%$ & $7.3 \%$ & $16.0 \%$ & $32.9 \%$ & $41.9 \%$ & $100.0 \%$ \\
\hline & & & $=42,946$ & value &, 000 & & & \\
\hline
\end{tabular}

The chi-square test of perceptions and attitudes of caring for the environment showed that the value of $\mathrm{p}=0.727$. This means that the value of $\mathrm{p}=0.727<\operatorname{sig} 0.05$. Based on this value, Ho is accepted, and H1 is rejected, or the perception does not significantly affect the students' environmental care attitude. More details can be seen in the following table 8.

Table 8. Cross Tabulation of Perception and Environmental Care

\begin{tabular}{|c|c|c|c|c|c|c|c|c|}
\hline & & & \multicolumn{6}{|c|}{ Environmental Care Attitudes } \\
\hline & & & Very Poor & Poor & Fair & Good & Very Good & Total \\
\hline \multirow{4}{*}{ 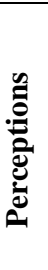 } & Poor & Frequency & 0 & 0 & 1 & 0 & 1 & 2 \\
\hline & & Percentage & $0.0 \%$ & $0.0 \%$ & $50.0 \%$ & $0.0 \%$ & $50.0 \%$ & $100.0 \%$ \\
\hline & Fair & Frequency & 0 & 1 & 5 & 7 & 9 & 22 \\
\hline & & Percentage & $0.0 \%$ & $4.5 \%$ & $22.7 \%$ & $31.8 \%$ & $40.9 \%$ & $100.0 \%$ \\
\hline
\end{tabular}




\begin{tabular}{llrrrrrr}
\hline Good & Frequency & 6 & 16 & 36 & 74 & 81 & 213 \\
& Percentage & $2.8 \%$ & $7.5 \%$ & $16.9 \%$ & $34.7 \%$ & $38.0 \%$ & $100.0 \%$ \\
\multirow{3}{*}{ Very Good } & Frequency & 1 & 9 & 15 & 36 & 58 & 119 \\
& Percentage & $0.8 \%$ & $7.6 \%$ & $12.6 \%$ & $30.3 \%$ & $48.7 \%$ & $100.0 \%$ \\
\multirow{2}{*}{ Total } & Frequency & 7 & 26 & 57 & 117 & 149 & 356 \\
& Percentage & $2.0 \%$ & $7.3 \%$ & $16.0 \%$ & $32.9 \%$ & $41.9 \%$ & $100.0 \%$ \\
& & $\mathbf{X}^{\mathbf{2}}=\mathbf{8 , 7 2 2} ; \mathbf{p}$ value $=\mathbf{0 , 7 2 7}$ & & & \\
\hline
\end{tabular}

\section{Multivariate Test}

The steps in the multiple regression test consist of three stages of testing, including the $\mathrm{t}$-test, $\mathrm{f}$ test, and the coefficient of determination. The t-test is used to determine whether there is an influence between the Knowledge variable (X1) and Environmental Care Attitude (Y) and the power between the Perception variable (X2) and Environmental Care Attitude (Y). Meanwhile, the $\mathrm{f}$ test serves to determine the influence of the three variables, namely Knowledge (X1), Perception (X2), on environmental care attitudes (Y). The coefficient of determination to determine the value of how much influence the variable Knowledge (X1), Perception (X2) simultaneously on the inconsistent attitude of environmental care (Y). The following is a linear regression test table 9.

Table 9. Multiple regression multivariate test results T-test

\begin{tabular}{lrrrrr}
\hline & \multicolumn{2}{c}{ Unstandardized Coefficients } & $\begin{array}{c}\text { Standardized } \\
\text { Coefficients }\end{array}$ & & \\
Variable & \multicolumn{1}{c}{ B } & Std. Error & Beta & & \multicolumn{1}{c}{ Sig. } \\
\hline Konstantina & 75.356 & 7.434 & & 10.136 & .000 \\
Knowledge & -.340 & .046 & -.375 & -7.469 & .000 \\
Perception & .220 & .097 & .114 & 2.277 & .023 \\
\hline
\end{tabular}

Based on the table, the t-count Knowledge value is -7.469 while the t-table is 1.962 obtained from the formula $\mathrm{t}=(\mathrm{a} / 2 ; \mathrm{n}-\mathrm{k}-1)$, while the knowledge sig value is 0.000 . The $\mathrm{t}$-count value for perception is 2.277 , and the t-table is 1.962 , while the perception sig value is 0.023 . Meanwhile for the f test can be seen in table 10 .

Table 10. Multivariate test results F test

\begin{tabular}{llrrrrr}
\hline Model & & Sum of Squares & df & Mean Square & \multicolumn{1}{c}{ F } & Sig. \\
\hline 1 & Regression & 23840.449 & 2 & 11920.224 & 28.358 & $.000^{\mathrm{b}}$ \\
& Residual & 148383.919 & 353 & 420.351 & & \\
& Total & 172224.368 & 355 & & & \\
\hline
\end{tabular}

In table 10 , it can be seen that the results of the $\mathrm{f}$ test are to determine the effect of Knowledge and Perception simultaneously on the environmental care attitude variable. Based on the table above, the si value of 0.000 is obtained, and for the f table value of 3.04 , which is 
obtained from the formula $\mathrm{f}$ table $=\mathrm{f}(\mathrm{k} ; \mathrm{n}-\mathrm{k})$, then $\mathrm{f}=2 ; 354$. The coefficient of determination test can be shown in the following table 11 .

Table 11. Coefficient of Determination Multivariate Test Results Hasil

\begin{tabular}{|c|c|c|c|c|}
\hline Model & $\mathbf{R}$ & R Square & $\begin{array}{l}\text { Adjusted R } \\
\text { Square }\end{array}$ & $\begin{array}{l}\text { Std. The error of } \\
\text { the Estimate }\end{array}$ \\
\hline 1 & $.372^{\mathrm{a}}$ & .138 & .134 & 20.50246 \\
\hline
\end{tabular}

From table 11 , it can be obtained that the $\mathrm{R}$ square value is 0.372 . This value indicates that the influence of knowledge (X1) and perception (X2) variables on environmental care attitudes (Y) is $37.2 \%$.

\section{Conclusion}

Based on the results of the study that the level of knowledge of students about geodiversity, biodiversity, and cultural diversity as a whole is in the fairly good category, while the perception level of students is in the good category, and the environmental care attitude of students in the Ciletuh-Pelabuhanratu geopark area is in good category. The results of the bivariate statistical analysis with the chi square formula showed that there was a significant relationship between the level of knowledge and the attitude of caring for the environment $(\mathrm{p}=$ $0.000<\operatorname{sig} 0.05$ ), while for the perception of the attitude of caring for the environment of the students there was no significant relationship $(p=0.727>$ sig. 0.05$)$. However, the results of the multivariate analysis of multiple regression tests show that there is an effect between knowledge $(\mathrm{sig}=0.000)$ or perception $(\mathrm{sig}=0.023)$ simultaneously on environmental care attitudes.

Knowledge and perception factors simultaneously affect the formation of environmental care attitudes by $37.2 \%$. The other factors that influence the formation of environmental care include personal experience, culture, other people who are considered important (significant other), mass media, educational institutions or religious institutions, and emotional factors within the individual.

\section{References}

[1] A. Fatimah, and Hardiyono. Geotourism Geopark Ciletuh: Geotrek Surrounds the Beauty of the Mega Amphitheater Ciletuh (The Magical Of Ciletuh Amphitheater). Bulletin Of Scientific Contribution, Volume 14, Number 1, April, pp.75 - 88. 2016

[2] H. Siregar, dkk. 2019. Analysis of Legal Protection Against Ciletuh National Geopark as a Geotourism Area in Sukabumi Regency, West Java Province. Surya Kencana Satu Journal: The Dynamics of Legal and Justice Issues Volume 10 Number 1 March. 2019

[3] Undang-undang Republik Indonesia No. 32. Concerning Environmental Protection and Management. 2009

[4] Darsihardjo et al. 1. Cletus Geopark Development Based on Community Participation as a Geotourism Area in Sukabumi Regency. Journal of Resort and Leisure Management Vol.13, No.1, April. 2016 
[5] M. Ruhimat and I. Triana. 2018. Understanding of Geography Teacher Towards Geopark as Learning Resources. Advances in Social Science, Education and Humanities Research, volume 251. Annual Civic Education Conference. Atlantis Press. 2018. https://doi.org/10.2991/acec$\underline{18.2018 .113}$

[6] A.R. Agusta \& Noorhapizah. Improving the Student's Cooperation and Environmental Care Skill using Outdoor Learning Strategy Outbound Variation. Atlantis Press. Advances in Social Science, Education and Humanities Research, volume 274. 1st International Conference on Creativity, Innovation, Technology in Education. 2018. DOI: https://doi.org/10.2991/iccite-18.2018.3

[7] R. Mulyana. Planting Environmental Ethics through Schools that Care and Cultured the Environment. JURNAL TABULARASA PPS UNIMED Vol.6 No.2, Desember, pp. 175-180. 2009

[8] Aurora. Educational Psychology Multidisciplinary Approach. Banyumas: CV Pena Persada. 2020

[9] M. Desfandi. Creating a Community with Environmental Care Character through the Adiwiyata Program. SOCIO DIDACTICA: Social Science Education Journal, 2 (1), pp. 31-37. 2015 DOI: http://dx.doi.org/10.15408/sd.v2i1.1661

[10] Presidential Regulation of the Republic of Indonesia No. 9. Regarding the Development of Geopark. 2019

[11] D.F. Vina. Sustainability. Bandung: Geological Engineering GEA Voice Magazine Vol 2. 2015.

[12] Minister of Energy and Mineral Resources Regulation Number 1. Regarding Guidelines for Determining Geoheritage. 2020.

[13] J. Supriatna. Biodiversity Conservation: Theory and Practice in Indonesia. Jakarta: Yayasan Pustaka Obor Indonesia. 2018

[14] Presidential Regulation of the Republic of Indonesia No. 9. Regarding the Development of the Geopark. 2019

[15] Sunaryo. Psychology For Nursing. JAKARTA: Penerbit Buku Kedokteran EGC. 2004

[16] Y. Tanjung, et all. Conceptual Knowledge Study. Bandung: CV Media Sains Indonesia. 2020.

[17] N.K. Suryani et al. 1. Organizational Behavior Textbook. Bali: Nilacakra Publishing House. 2019

[18] Rusman. Learning \& Learning: Standard Oriented Educational Process. Jakarta: Penerbit Kencana. 2017.

[19] D. Zuchdi. Attitude Formation. Cakrawala Pendidikan No. 3, Year XIV, November. 1995

[20] H.S.Yunus. Contemporary Regional Research Methods. Yogyakarta: Pustaka Pelajar. 2010.

[21] J.W. Cresswell. Research Design. Yogyakarta: Penerbit Pustaka Pelajar. 2014.

[22] S. Santoso. Multivariate Statistics.Jakarta: PT Elex Media Komputindo. 2010 